\title{
Institutional Restructuring to Sustain Regulatory Reform in Indonesia
}

\author{
Wicipto Setiadi \\ Faculty of Law, Universitas Pembangunan Nasional "Veteran" Jakarta, Indonesia. \\ E-mail:wiciptos@gmail.com
}

\section{ARTICLE INFO}

Keywords:

Drafting Regulations;

Institutional Restructuring;

Regulatory Reform

How to cite:

Setiadi, W. (2019).

"Institutional Restructuring

to Sustain Regulatory

Reform in Indonesia,"

Hasanuddin Law Review,

5(1): 120-131

DOI:

10.20956/halrev.v5i1.1699

\begin{abstract}
There are numerous institutions in Indonesia that form regulations with its exceeding number of regulators may result in poor quality regulations. The outcome leads to regulations being over-regulated, overlapping, disharmony, and conflict. Hence, steps are needed to be taken to overcome in order for more improved and comprehensive regulation in Indonesia. A key factor to overcome poor conditions of regulation in Indonesia is by applying the good regulatory practice. Referring to the practice, there are several standards or principles that can be used as references. Apart from this, taking institutional restructuring into consideration, an establishment of a single institution to form regulations that are strong, full authority to conduct the process of forming regulations. The paper presented is based on literature reviews and documents relating to the subject at hand. From this research, systematic writing was produced using a juridicalanalytical approach. This study aims to support the establishment of single-centered Ministry of Laws or Regulation with a strong organizational structure filled with qualified experts and capable professionals.
\end{abstract}

Copyright ( 2019 HALREV. All rights reserved.

\section{Introduction}

Considering current state of laws and regulations ${ }^{1}$ that are not present-day, regulatory reform is perceived as a critical matter to implement in Indonesia. Outdated regulations, ${ }^{2}$

1 The term legislation is often used with another name, namely regulation. The official term used in Law Number 12 of 2011 concerning the Establishment of Legislation is legislation. In this article the author uses both terms simultaneously and exchanges with the same meaning, sometimes using regulatory terms sometimes also uses statutory terms.

2 Until now there are still some legacy laws in the days of the Dutch East Indies Government that are still valid. These laws include the Criminal Code (KUHP, Wetboek van Strafrecht), Civil Code (KUH Perdata, Burgerlijk Wetboek), Civil Procedure Code, Commercial Law Book (KUHD, Wetboek van Koophandel) . This Dutch East Indies Government legacy law is still valid because of Article I of the Transitional Rules of the 1945 Republic of Indonesia Constitution which stipulates: "All existing laws and regulations still remain in force as long as they have not been held according to this Basic Law". 
possibility of overlapping regulations and disharmony creates conflict ${ }^{3}$. Taking this into account, sectoral egos, ministry/institutional egos, and regional egos cannot be overlooked. This issue disrupts the general development goals and specific legal development goals. The purpose of development is an effort to achieve the goals of the country as stated in the fourth paragraph of the 1945 Republic of Indonesia Constitution, which protects the entire nation and all of Indonesia's warfare, advances public welfare, educates the nation's life and participates in carrying out world order based on independence, eternal peace and social justice.

Regulatory Reform refers to change, improvement, and structuring in the field of regulation with its main objective to improve the quality of regulation. ${ }^{4}$ Regulatory reform is an effort that is in line with the policies announced by the President Joko Widodo (Jokowi) to improve the quality of regulation in Indonesia. The formulation of regulation is actually a state or government monopoly (absolute authority), but the process of its formation must involve various stakeholders, including non-governmental organizations (NGOs). Although NGOs do not formulate regulations, they have a big influence in the process of government decision-making and the legislative process. ${ }^{5}$ The involvement of NGOs in the legislative process is based on the principle of transparency. ${ }^{6}$

The National Development and Planning Agency (BAPPENAS) ${ }^{7}$ have carried out a mapping to describe the quality of regulations in Indonesia as follows:
a) Hyper-regulation;
b) Conflicting;
c) Overlapping;
d) Multi interpretation;
e) Inconsistency;
f) Ineffective;
g) Creating unnecessary burdens;
h) Creating a high-cost economy.

National Development Planning Agency (hereinafter, BAPPENAS') plotted the quality of regulations above 6 years ago in 2012. Based on the observations of the author, such conditions have until now not been an attempt towards improvement, in fact it is very likely that the conditions have worsened. Such conditions are influenced by the institutional role of legislators. The implications of the conditions stated above are: 8

a) Regulatory problems have an impact on the effectiveness of regulatory implementation. The ineffectiveness of implementing regulations will result in

3 Wicipto Setiadi. (2018). Simplification of Legislation in the Framework of Supporting Ease of Business, Rechts Vinding Journal: National Law Development Media, 7 (3): 321-334.

4 Diani Sadiawati. (2018). Synergy of Policy and Regulation in Facing Global Challenges, Paper on National Seminar on Legal Reform, Republic of Indonesia Cabinet Secretariat, Jakarta, November 28, 2018, p. 6.

$5 \quad$ Ibid, Page 12.

6 See Article 5 letter a of Law Number 12 of 2011 concerning Establishment of Legislation.

7 National Development Planning Agency (Bappenas). (2012). Workshop "Mapping the Results of Identification of Potentially Problematic Sector Laws" was held by the Directorate of Analysis of Legislation, National Development Planning Agency (Bappenas), Jakarta, December 5, 2012.

8 Ida Bagus Rahmadi Supancana. (2017). An Idea About Grand Design of Indonesian Regulatory Reform, Center for Regulatory Research in collaboration with British Embassy Jakarta, Publisher of Atma Jaya Catholic University, 2017, p. 5. 
obstacles to the achievement of national development. Obstacles towards achieving national development will have an impact on achieving the goals of national development.

b) Negative perceptions of the Indonesian legal system are considered ineffective and not conducive to the national economy, especially increasing investment risk.

c) Legal uncertainty and business uncertainty raise doubts about investing. Low investment results in low economic growth, rising unemployment, and increasing poverty rates.

d) Indonesia's low ranks by various international ranking institutions.

e) Low competitiveness to attract investment.

f) A poor regulatory system reflects poor governance.

Encouraged by the conditions said above, efforts on regulatory reform becomes an essential key to accelerate the improvement of regulations which is expected to boost business climate and investment in Indonesia so as to encourage economic growth, increase employment, and reduce poverty. With improved regulations, it is hoped that there will not be unnecessary burden, less multi-interpretation, less overlapping, and less disharmony. Furthermore, with better regulations, it is predicted that the implementation will be more effective and higher level of community compliance.

The problems raised as a basis in discussing and elaborations on this paper are: 1) How is the formation of good regulation? 2) Will various institutions who formed regulations affect the quality of regulation? 3) What are the steps needed to take towards solving these institutional problems that form too much regulation?

\section{Method}

The method of research used based on literature reviews and documents at hand relating to the subject matter. From this research, systematic writing was produced using a juridical-analytical approach and qualitative results was obtained. Secondary legal materials used include books, scientific works, journals and research results related to the objects discussed. Data collection was also equipped with legal articles from the internet or other scientific articles that can support the coherence of the data in this study. Data from the results of this study were then analyzed in depth, holistic, and comprehensively.

\section{Existing Conditions of Institutions Forming Regulations}

Nowadays, there are several institutions involved in the formation of regulations in Indonesia. The large number of institutions that make up the regulations also encourages a growing number of laws and regulations. The large number of institutions that form legislation and the number of laws and regulations will greatly influence the quality of regulations. The more institutions involved in the formation of legislation and the 
number of laws and regulations, the greater the potential for the creation of legislation of low quality and disharmony. 9

OECD assessed that coordination regarding regulations in Indonesia which seems to be an "expensive" attribute, the lack of coordination makes it prone to overlapping with other regulations. Regulations made by rural regions often collides with higher regulations from central government. More so, the government is expected to encourage a more holistic approach (a whole government approach) in each policy formulation / formation of regulations so as to produce consistent and higher quality regulations. From an institutional perspective, Indonesia currently does not have institutions that specifically have a formal function to review regulations. ${ }^{10}$ However, if we base it on Trias Politica ${ }^{11}$ teachings, the institutions involved in the formation of legislation can be grouped into 3 institutions; the executive, legislative and judicial institutions. These institutional roles are very important in the process of regulatory reform. Below describes the institutions whose role is to form "existing" regulations.

\subsection{Executive Institution}

Most institutions that form legislation (regulations) are located in the branch of executive power. In this branch of executive power, it can be distinguished into institutions that form the central level of legislation and regional legislative institutions. The central regulators can be calculated from the number of ministries and non-ministerial institutions that exist at this time. Keeping in mind, a total of 34 Ministries that can create regulations, with an exception of 4 coordinating ministries. With that many ministries, we can estimate the professionals in that area as regulators in the branch of executive power in the ministry of institutions. Such conditions occur also in the branch of executive power in non-ministerial institutions. The number of non-ministerial institutions that exist will result in the increasing number of human resources forming (drafting) regulations.

The central government institutions that form regulations role is on Constitution, Government Regulations, Presidential Decree, Ministerial Regulation, Regulation of the Head of Non-Ministerial Institution, regulation of independent institutions, and other regulations.

Regional regulation institutions consist of Provincial-level Institution and regency or city level. Under Provincial-level institution, the governor along with its offices and Regional People's Representative Assembly are in charge of regional regulations. We can also conclude that the exceeding number of regulators from 508 regency and city under 34 province Indonesia leads to an overwhelming amount of human resources as regulators. ${ }^{12}$ From this amount, we can expect the amount of human resources needed and used to form regulations on provincial and district government institutions.

9 Wicipto Setiadi. (2017). Process of Harmonization as an Effort to Improve the Quality of Legislation, Journal of Indonesian Legislation, Vol. 4 Number 2, June 2007, Directorate General of Laws and Regulations, Ministry of Law and Human Rights, p. 46.

10 Bappenas. (2015). Workshop “Regulatory Reform in Indonesia”, Bappenas \& OECD, Jakarta, 25 Maret 2015.

11 The Trias Politica doctrine was first introduced by John Locke (1632-1704) and later developed again by Montesquie (1689-1755) which came to be known as the teaching of "separation of power". The thought of John Locke regarding Trias Politica was outlined in Magnum Opus written in his book entitled Two Treatises of Government which was published in 1690. Then, in its development the teachings of "separation of power" transformed into teachings "distribution of power (division of power) ".

12 Source: Directorate of Regional Arrangement, Special Autonomy, and Regional Autonomy Council, Directorate General of Regional Autonomy, Ministry of Home Affairs, 2014. 
The role of legislative institutions in the regional executive branch is from the establishment of Provincial Regulations, Governor Regulations, Regency/City Regulations, Regents/Mayors regulations, etc.

\subsection{Legislative Institution}

In order to establish regulations, the legislature consists of: 1) Indonesian People's Consultative Assembly (MPR RI); 2) People's Representative Council of Indonesia (DPR $\mathrm{RI})$; and 3) Regional Representative Council of the Republic of Indonesia (DPD RI).

The Republic of Indonesia MPR consists of 692 members from the Parliament and the DPD. 13 The Republic of Indonesia MPR are supposedly to formulate regulations of Indonesia's Law Act. That said, this role has hardly ever taken into account within a 5year period. The last role of MPR members to formulate Law Act was carried out in the period of the MPR RI membership in 1999 - 2004, namely 1999 (I Amendment to the 1945 Constitution), 2000 (Amendment II to the 1945 Constitution), 2001 (Amendment III of the 1945 Constitution), and 2002 (IV Amendment to the 1945 Constitution). After the period 1999 - 2004 until now (the period 2014 - 2019), the role of the Republic of Indonesia MPR as a legislator (UUD) was never implemented again. It is still uncertain whether MPR RI role for the period 2019-2024 will continue to draft Law Act or not.

The members of Indonesia's Parliament is made up of $560^{14}$ elected people who came from Indonesia's various political parties. DPR also has a role to draft laws. The bill from the Republic of Indonesia Parliament can be submitted by members, commissions, joint commissions, or the Legislation Body. If we base it on the number of members of the DPR, then there are 560 human resources forming laws in the DPR RI. This number does not include human resources (HR) as researchers and experts, who have the status of State Civil Apparatus (ASN) who are in the Legislation Body, the Secretariat General of the DPR and the DPR Expertise Agency.

Currently, there are 13215 members of Indonesia's Regional Representative Council (DPD RI) whom are representative from 33 province with North Kalimantan ${ }^{16}$ as an exception. Based on Indonesia's 1945 Constitution, DPD RI can submit a bill relating to regional autonomy, central and regional relations, development, division, and joined regions, management on natural resource in the region, as well as relations on central and regional finances. ${ }^{17}$ Although there are 132 members involved, there is an addition of human resources of researchers and experts under the DPD Secretariat General.

\subsection{Judicial Institution}

The judicial institutions that play a role in formulating regulations are the Constitutional Court (MK) and the Supreme Court (MA). Unlike other legislative institutions, the Constitutional Court and the Supreme Court are the makers of negative regulation as opposed to forming positive regulations. Positive and negative are seen from their role. Institutions that form positive regulations are institutions that are directly involved in

13 The number of MPR RI members for the period 2014-2019.

14 This number is the number of members of the Republic of Indonesia DPR for the period 2014-2019.

15 This number is the number of members of the Republic of Indonesia DPD for the period 2014-2019.

16 The Province of North Kalimantan is the youngest province in Indonesia that was formed under Law No. 20 of 2012 concerning the Establishment of the North Kalimantan Province. For the membership of the DPD RI in 2014 - 2019 the Province of North Kalimantan there is no representative yet.

17 See: Article 22D of the 1945 Republic of Indonesia Constitution. 
the formation of regulations, namely the DPR, Government (President) and DPD. It is said to be a form of negative regulations because of the role of the Constitutional Court and the Supreme Court as institutions that conduct judicial review of laws and regulations.

The role of the Constitutional Court is to test statutory regulations (judicial review) at the level of the Republic of Indonesia's 1945 Constitution. ${ }^{18}$ Whereas the Supreme Court acts as an institution that conducts judicial review of laws and regulations that are hierarchically under the law against higher regulations. ${ }^{19}$ However, in practice this negative role can also shift to a positive role. This only occurs when the judiciary institution not only states articles or verses that opposed to Indonesia's 1945 Constitution, but participates in formulating or correcting norms in testing regulations. ${ }^{20}$

\section{Examining Reformation of Legal Forming Institution}

\subsection{Executive Institution of Legal Forming}

Considering the huge number of regulations, Republic of Indonesia President, Mr. Joko Widodo gives directive for Ministries/Agencies have to be focus more on the assessment of formulating regulation on the basis of quality. The directive was given on Executive Meeting on 17 January 2017.21

In the case of regulation, the success or failure of regulatory reform is largely determined by the institutional role on legislation. Considering, the huge number of regulations, it is necessary to have a remodel on the institutions. In reference to numerous countries that have implemented regulatory reform, one of the key factors on the success of regulatory reform is appropriate and authoritative institutions. In those countries, the legislative body is putted into single centred body. To put into practice, restructuring institution must be taken seriously and thoroughly by state policy makers. Previous studies on countries succeeded on regulatory reform shows that that there is a strong link within political will and leadership.

As comparison, countries like United Kingdom, Australia, Belgium, Iceland, South Korea, Sweden, Switzerland, and Spain were successful on implement regulatory reform

18 See Law Number 24 of 2003 concerning the Constitutional Court as amended by Act Number 8 of 2011.

19 See Law Number 14 of 1985 concerning the Supreme Court as amended by Act Number 5 of 2004 and was last amended by Law Number 3 of 2009.

20 As one example of the Constitutional Court's shifting its role to be positive in the formation of the Law, it can be seen in the Court Decision No. 82 / PUU-XII / 2014 dated 29 September 2014 in the Judicial Review of Law Number 17 of 2014 concerning the MPR, DPR, DPD, and DPRD (MD 3) which added the formulation in Article 97 paragraph (2) by adding phrases: "prioritizing representation of women according to the balance of the number of members of each faction ". Thus, the formulation of Article 97 paragraph (2) of its complete formulation becomes: The head of the commission consists of 1 (one) chairperson and a maximum of 3 (three) deputy chairpersons are elected from and by commission members in a fixed package based on the proposed fraction with the principle of deliberation to reach consensus by prioritizing women's representation according to the balance of the number of members of each faction. The MK decision also applies to other articles or verses in Law Number 17 of 2014, namely Article 104 paragraph (2), Article 109 paragraph (2), Article 115 paragraph (2), Article 121 paragraph (2), Article 152 paragraph ( 2), Article 158 paragraph (2). Law Number 17 of 2014 has been made the second time, the latest with Law Number 2 of 218 concerning the Second Amendment to Law Number 17 of 2014 concerning the MPR, DPR, DPD and DPRD.

21 Secretary Cabinet of Republic Indonesia, National Seminar on Law Transformation: Towards the Effective and Efficient Regulation, Jakarta, 28 November 2018, page 4. 
since it was directly led by Heads of Government. ${ }^{22}$ Other countries suchlike Turkey, Norway, New Zealand, Poland, Hungary, Mexico, Czech carried the agenda under Minister Command. Other case like Australia, Germany, and United States implemented the agenda within their special institution. ${ }^{23}$

As for the case in Indonesia, regulatory reform must be directly led by the President as the head of the State. 24 The process of regulation making, Indonesia still faces classical problem particularly conflicts of interest within institution and sectoral ego. As the head of the state, the President's vision is supported by Ministries, Non-Ministries, and Regional Government. The President's vision turns to be the basis of the government work plan. On this mechanism, each of Ministries, Non-Ministerial Institutions, and Regional Government have to obey with it. The cooperation among all stakeholders aims to end conflicts of interest and sectoral ego. This idea is reflected on 4th paragraph of Opening Constitution 1945 of the Republic of Indonesia. ${ }^{25}$

In the practice of regulatory reform, the President needs to be assisted by an institution that has full authority and capacity. On the present writer point of view, currently the process of formulating regulation within executive level go through various institutions suchlike; Ministry of Law and Human Rights (National Legal Development Agency and Directorate General of Legislation), Ministry of State Secretariat, Ministry of Cabinet Secretariat (i.e Presidential Decree), and Coordinating Ministry (Coordinating Ministry for Political, Legal and Security Affairs, Coordinating Ministry for Human and Cultural Development, Coordinating Ministry of Maritime Affairs, and Coordinating Ministry for Economic Affairs). The Coordinating Ministry are in charge of pending draft of legislation cannot be settled by the Ministry/Institution within its line coordination.

It is important to understand, that the current mechanism actually adds length and longer the process of the regulation formulation. Another issue that makes it more complicated is the lack of competent legal drafter. The regulation formulation begins with request from the Ministry of State Secretariat to the relevant ministries before the draft legislation is signed or stipulated to the President. Thus, the process of assisting legislation takes a long and complicated procedure.

OECD recommend to have three regulatory strategic institutions on the executive level namely as; Regulatory Oversight Body, Regulatory Advisory Body and Regulatory Promotional Body:26

a. Regulatory Oversight Body carries out several functions; public consultation on formulating future regulations, report the progress of regulatory reforms implemented Ministries, analyse the cost and benefit of regulations, and advocate to promote the quality of regulations. ${ }^{27}$

22 Read Jacobzone, S, C. Chi and C. Miguet. (2007). Indicators of Ragulatory Management System, OECD Working Paper on Public Governance, OECD Publishing, 2007/4, page. 63-67.

23 Ida Bagus Rahmadi Supancana, Op. Cit. page. 13

24. See: Article 4 paragraph (1) of the 1945 Republic of Indonesia's Constitution.

25 The 4th paragraph of the Preamble of the 1945 Constitution of the Republic of Indonesia states: "... The Indonesian government protects the entire Indonesian nation and all of Indonesia's unity and for advancing public welfare, educating the nation's life and participating in carrying out world order based on freedom, eternal peace and justice social...".

26 See OECD, "Guiding Principles for Regulatory Quality and Performance" in "OECD Taking Stock of Regulatory Reform", 2005, p. 62.

27 Ida Bagus Rahmadi Supancana, Loc.Cit. 
b. Regulatory Advisory Body perform functions; receive inputs from the government to analyse regulations in a bigger scope and gather various views from stakeholders regarding certain regulations as part of the implementation of public consultations. ${ }^{28}$

c. Regulatory Promotional Body executes the efforts that have been and will be carried out in implementing regulatory reform activities. ${ }^{29}$

Considering the condition, Indonesia should have in depth analysis to establish such institution, it is important to also reflect Indonesia's condition. First of all, before determines the type of institution that is the most suitable/ideal to deal with various legislative institutions on executive level, the following criteria are presented:30

a. Single centred body

b. Directly reports to the President

c. Cross sectoral authority

d. Strategic coordination position

e. Credibility, dignity and neutrality

f. Highly capable human resource

Indonesia Minister Cabinet Secretary, Mr. Pramono Anung on National Seminar of Legal Reform: Towards Effective and Efficient Legislation Regulations stating that one of the solutions to regulation problem is by strengthening institution capacity. In this case, strengthening means forming single centred body. ${ }^{31}$

The creation of single centred body means to uphold the President's position, since the President still be one in charge fully. The urgency to frame single centred body is due to current situation of regulation that is complicated and its consequences. Hence it is necessary to create Ministries specifically in charge of regulation that its duties are not overlap with other Ministries. Due to the upcoming Presidential election on July 2019, it is necessary to speed up the preparation of one-door legislative institution.

It is during the administration of President Abdurrahman Wahid (1999-2004) there was once a Department of Law and Legislation placed within Ministry of Justice. One of the objectives is to strengthen the institutions formulating regulation. At that time, the legislation issue was the duties and functions of Directorate General of Laws and Regulations. The formation of the Directorate General of Laws and Regulations is expected to improve the quality of legislation, but results came back that the implementation was not that smooth and easy. The process of formulating legislation still takes a long process. Presently, the existence of institution needs to support the duty of National Legal Development Agency and the Directorate General of Legislation, and also engage with other Ministry of State Secretariat (Deputy of Law and Legislation legislation), Cabinet Secretariat, Coordinating Ministry, and other Ministries or Institutions.

During the second administration of President Susilo Bambang Yudoyono 2009-2014, a new office was held under the Ministry of Law and Human Rights, namely the Deputy Minister of Law and Human Rights. Deputy Minister of Law and Human Rights in

28 Ibid.

29 Ibid.

30 Ibid, page. 99

31 Keynote Speech Cabinet Secretary at the National Seminar, Legal Reform: Towards Efficient and Effective Legislation, Republic of Indonesia Cabinet Secretariat, Jakarta, 28 November 2018, p. 12. 
charge of legislative issues. Considering the various duty of Ministry of Law and Human Rights it would be hard to concentrate only on the issue of regulation, therefore the issue of regulation was imposed under the Deputy Minister of Law and Human Rights. Result confirms that $\mathrm{s}$ for the regulation issue it is coordinated under the echelon 2 only, namely the National Law Development Agency and the Directorate General of Laws and Regulations. In this mechanism, Deputy Minister of Law and Human Rights is in charge of other issue but not regulation. In short, it can be concluded that the goal of strengthening the institutions that form regulation is not fully achieved.

Reflecting the regulatory condition in Indonesia, the need to have single centred body becomes very urgent. Considering to that matter, the must be a depth discussion regarding the ideal type institution for Indonesia. Taking into account of previous explanation, the institutions will take place on executive level and will be in the form of Ministry-Level. As for the nomenclature it can be either Ministry of Regulation or the Ministry of Law. ${ }^{32}$ The Ministry will focus on the issue of formulation of regulation only and not mixed up with other tasks and functions. As for the human resource, the individual should not be filled with people from political parties or affiliated with political parties, but run by professionals who are truly experienced and understand the laws and regulations. The Ministry has to fully understand both theoretical and practical aspects to support good regulatory practice.

Reflecting the Law Number 39 of 2008 concerning State Ministries, actually there is a regulation that limits the number of ministries to be not be more than 34 Ministries. ${ }^{3}$ Currently the number ministry (2014-2019) is exceed to more than 34 Ministries. Following this issue, the number of ministries can be reduced by the President considering several matters as follow: 34
a. Efficiency and effectiveness
b. Modify and/or develop duties and functions
c. Scope of workload
d. Continuity, harmony and integration
e. Increased government performance
f. Other government duties
g. Terminology

The establishment of the Regulatory Ministry or the Ministry of Legislation should be supported by a letter emphasizing its efficiency and effectiveness. Such changes can be made at Coordinating Ministry. To add, the Coordinating Ministries also supposed to solve problem within line Ministries.

If the single centred body exist, the next question would be the role National Law Development Agency of the Ministry of Law and Human Rights, Directorate General of Laws and Regulations (Ministry of Law and Human Rights), Deputy of Law and Legislation of the Ministry of State Secretariat, and Ministry of Cabinet Secretariat. Since all of them are also involved in regulatory making process. The ideal solution is to integrated those Ministries into Ministry of Regulation or the Ministry of Legislation. The location of Ministry of Law or Ministry of Regulation must also close to the Office of the President. The Cabinet Secretariat and the Presidential Staff Office are also

32 Compare this with South Korea which uses the nomenclature of Ministry of Government Legislation (Ministry of Government Legislation)

33 See: Article 15 of Law Number 39 of 2008 concerning State Ministries

34 See: Article 18 of Law Number 39 of 2008 concerning State Ministries 
integrated into the Ministry of State Secretariat and the Ministry of State Secretariat no longer in charge of legislation.

Therefore, Ministry of Law or the Ministry of Regulation will be the only one vocal point placed executive level. ${ }^{35}$ Then the function on regulatory formulation on existing Ministries will be eliminated, and for the draft legislation will submitted to the Ministry of Legislation or the Ministry of Regulation. Since the Ministry of Law or the Ministry of Regulation will have duty to coordinate with all ministry that is still in sectoral approach, to get them more aligning into President's vision and mission, the interests of society, nation and state. In this mechanism, the President just needs to sign/ratify/stipulate the legislation draft on his desk only, unless there are things that still need to be clarified. Thus, the process of establishing legislation is integrated within one door, and it is no longer through many doors as it is today.

\subsection{Legislative Sector Institutional Restructuring}

The formulation of legislation through many doors also occurs in the legislature process. The legislators in the DPR RI consists of commissions, joint commissions, special committees, bodies, and the members of the DPR. DPR must also implement regulatory reform and establish one gate regulatory process making. Therefore, it will increase the quality of regulation. It will also add the quality of legislation process since, the Law Act will be the basis of regulation.

The basic reform that needs to be conduct within legislative level is to reinforce to the DPR RI Legislation (Legislative Body) as the only institution that formulate the Law. As for other unit such as commissions, joint commissions, other complementary bodies and will focus on bill of proposal. As for the DPD, it will support the proponent of the bill, considering its authority on regional autonomy, regional expansion, and centralregional relations as stated in the 1945 Republic of Indonesia Constitution. In addition, DPR needs to be supported by professional individual. OECD recommend steps to be taken for the Parliament as follows: 36

a. Commission in charge of regulatory reform

b. Commission in charge of reviewing the draft bill

c. Certain body to review lower regulation

d. Specified regulatory quality criteria

e. Commission to review the progress of regulatory reform

According to OECD member countries, the DPR Legislative Assembly that is best to carry out these duties and responsibilities. Since the commission will have high duty and responsibility, then it would be better for DPR RI Legislative Assembly to focus and concentrate on handling the formation of the Law only without being burdened with the other duties. Reflecting its performance on the past years, DPR were not that serious in discussing the bill because of the carrying other tasks that they have to do. Many DPR

35 Compare this with Pramono Anung in the Keynote Speech Cabinet Secretary at the National Seminar, Legal Reform: Towards Efficient and Effective Legislation, Republic of Indonesia Cabinet Secretariat, Jakarta, 28 November 2018, p. 12 who use the term leader

36 Jacobzone, S, S Choi and C Miguet. (2007). Indicators of the Regulatory Management System, OECD Working Paper on Public Governance, OECD Publishing. Also read: Ida Bagus Rahmadi Supancana. (2017). An Idea on Grand Design of Indonesian Regulatory Reform, Regulatory Study Center and British Embassy Jakarta, Publisher of Universitas Katolik Indonesia Atma Jaya, p. 101. 
members are exposed for being presence at RUU discussion meeting very shortly, then left on the grounds that there were other duties.

Considering the central and strategic role of the DPR Legislative Assembly, it has to be supported by expert staff to increase quality of the Act. In the context of DPR regulatory reform, various approaches and awareness must be taken. The implementation of regulatory reform will need every party's willingness, since the existing commissions in the DPR presently will not want to give up voluntarily as the legislators. It should be noted that the role as the legislator is a very strategic with having a big authority, so that the process of integrating the law in the DPR will face various opposition. One thing that need to be taken as consideration is it will be hard for regulatory reform to be conducted without involving the DPR, considering role in the formation of the Law. Inevitably, it must be admitted that in the process of forming the law, political aspects were more prominent than the legal aspects.

\subsection{Judicial Institutional Restructuring}

Although the role is not as strategic as the executive and judicial institutions, without the involvement of judicial institutions the regulatory reform will not work well. In the case of Judicial Institutional Restructuring the legislators are the Constitutional Court (MK) and the Supreme Court (MA). The role of MK and MA is to assess negative legislative regulations, or to request for judicial review of legislation.

In the context of regulatory reform, the Constitutional Court and the Supreme Court decide that judicial review should not only interpret the formal judicial aspects, but also consider the good regulatory practice. Hence judges should also consider of cost and benefit aspect, meaning that the decision to formulate calculate both aspect of benefit and cost of making the regulation as well as the impact to the society. This is very important to prevent massive losses as a result of the decision. Therefore, in order to support regulatory reform, the quality of a judge or panel is very crucial. Constitutional Court and Supreme Court should rely on professional, integrity intellectual quality, and also wisdom.

In the framework of integrating the petition for judicial review of laws and regulations, it is also necessary to think that in the future there will no longer be a distinction between judicial review of the Law to the Constitutional Court and judicial review of laws and regulations under the Act, but all requests for judicial review. Hence, the laws and regulations under the Act were submitted to one institution, namely the Constitutional Court. As a result, MA should focus and concentrate on handling non-judicial review legal disputes.

\section{Conclusion}

Indonesia have numerous institutions on regulatory making, and yet each of them are very ego sectoral. In the practice to implement good regulatory practice, the restructuring of institutions on regulatory making is the solution to have high quality on regulations. The needs of having harmony in regulation turns to be important so that it will not lead various problem suchlike; overlap, disharmony, conflict, duplication. The existence of single centred body will have a huge contribution to regulatory reform. In this case, single centred body and regulatory reform needs to be supported by political will of the President. The President then will give directive to line Ministries and stakeholders to support restructuring body. 


\section{References}

Constitutional Court Decision Number 82/PUU-XII/ 2014 dated 29 September 2014 in Judicial Review of Law Number 17 of 2014 concerning MPR, DPR, DPD, and DPRD (MD 3).

Diani Sadiawati. (2018). Synergy of Policy and Regulation in Facing Global Challenges, Paper on National Seminar on Legal Reform, Republic of Indonesia Cabinet Secretariat, Jakarta, November 28, 2018.

Directorate of Regional Arrangement, Special Autonomy, and Regional Autonomy Council, Directorate General of Regional Autonomy, Ministry of Home Affairs, 2014.

I Dewa Gede Palguna. (2013). Constitutional Complaint of Legal Efforts against Violations of Constitutional Rights of Citizens, Sinar Grafika, Jakarta.

Ida Bagus Rahmadi Supancana. (2017). An Idea About Grand Design of Indonesian Regulatory Reform, Center for Regulatory Research in collaboration with British Embassy Jakarta, Publisher of Atma Jaya Catholic University.

Jacobzone, S, C. Chi and C. Miguet. (2007). Indicators of Ragulatory Management System, OECD Working Paper on Public Governance, OECD Publishing, pp. 63-67.

National Development Planning Agency (Bappenas). (2012). Workshop "Mapping the Results of Identification of Potentially Problematic Sector Laws" was held by the Directorate of Analysis of Legislation, National Development Planning Agency, Jakarta, December 5, 2012.

National Development Planning Agency (Bappenas). (2015). Regulatory Reform in Indonesia, the Workshop was held by Bappenas \& OECD, Jakarta, March 252015.

Secretary Cabinet of Republic Indonesia, National Seminar on Law Transformation: Towards the Effective and Efficient Regulation, Jakarta, 28 November 2018.

The Organization for Economic Cooperation and Development (OECD). (2005). Guiding Principles for Regulatory Quality and Performance, in the OECD Taking Stock of Regulatory Reform.

Wicipto Setiadi. (2017). Process of Harmonization as an Effort to Improve the Quality of Legislation, Journal of Indonesian Legislation, Vol. 4 Number 2, June 2007, Directorate General of Laws and Regulations, Ministry of Law and Human Rights.

Wicipto Setiadi. (2018). Simplification of Legislation in the Framework of Supporting Ease of Business, Rechts Vinding Journal: National Law Development Media, 7 (3): 321334.

\section{Conflict of Interest Statement:}

The author(s) declares that the research was conducted in the absence of any commercial or financial relationships that could be construed as a potential conflict of interest.

Copyright (C) 2019 HALREV. All rights reserved. 